\title{
İstanbul Paleozoyik İstifi'ndeki Dayklar ile Yan Kayalarının Dayanım ve Deformasyon Özelliklerindeki Farklılıklar
}

\author{
The Differences of Strength and Deformation Properties of Dikes and \\ Host Rocks in the Paleozoic Sequence of İstanbul \\ Ömer ÜNDÜL ${ }^{1} \mathbb{D}$, Buğra C. ÇOBANOĞLU² $\mathbb{D}$, Feyat TAZ ${ }^{2} \mathbb{D}$ \\ ${ }^{1}$ İstanbul Üniversitesi - Cerrahpaşa, Mühendislik Fakültesi, Jeoloji Mühendisliği Bölümü, Avcılar, 34320 İstanbul, \\ Türkiye

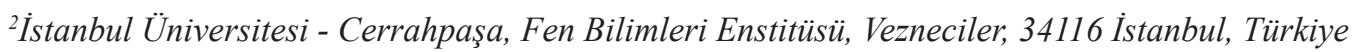

Geliş (Received): 19 Eylül (September) 2017, Düzeltme (Revised): 01 Haziran (June) 2018, Kabul (Accepted): 03 Ağustos (August) 2018

\section{ÖZ}

Nüfus artışına bağlı olarak yeni yerleşim alanlarına gereksinim artmakta, bu alanlarda, altyapı hizmetleri ve diğer mühendislik amaçlı pekçok yapının inşası zorunlu hale gelmektedir. Farklı türdeki mühendislik yapılarının (Örneğin altyapı hizmetleri, derin kazılar, tüneller vb.) inşaası 1900'lü yılların ikinci yarısından itibaren İstanbul'da yoğun olarak devam etmektedir. Önümüzdeki yakın gelecek için de pekçok büyük mühendislik projesi planlanmaktadır. Günümüzde inşa edilen yapılar öncekilere göre daha büyük boyutlarda ve daha derinde yapılmaktadır. Böylece, planlayıcı ve uygulayıcı mühendisler daha fazla jeolojik belirsizliğin yarattığı jeo-mühendislik sorunlarla karşılaşılmaktadır. İstanbul'daki büyük mühendislik projelerinin önemli bir kısmı son yıllarda İstanbul Boğazı'nın her iki yakasında ve genelde İstanbul Paleozoyik istifinde yoğunlaşmaktadır. Bu istif genel olarak çökel kayalardan oluşmaktadır. Çökel kayalar pekçok yerde farklı bileşimlerde, belirgin olmayan yönlerde ve boyutlardaki (milimetreden birkaç metre boyutlarına kadar) dayklar tarafından kesilmektedir. Bu istifteki çökel kayaları kesen dayklar pekçok tünel projesinde, TBM sıkışması, stabilite ve su problemleri vb. beklenmeyen ve istenmeyen durumları oluşturmaktadır. Bunların sonucunda da projelerde zaman kayıpları ve maliyet artışları yaşanmaktadır. Bu çalışmanın amacı, İstanbul'daki daykların eksenel yükler altındaki dayanım ve deformasyon özelliklerinin belirlenmesidir. Ayrıca, çalışılan kayaçların gevreklik özellikleri de değerlendirilmiştir. Bu bağlamda, tek eksenli sıkışma dayanımı ve dolaylı çekme dayanımı deneyleri dayklar üzerinde gerçekleştirilmiştir. Bunlara ek olarak, daykların ve yan kayaçlarının temel kaya özelliklerine göre mühendislik davranışları karşılaştırılmıştır. Deneylerden elde edilen sonuçlara göre daykların ve yan kayaçların tek eksenli sıkışma dayanımları sırasıyla 46-277 MPa ve 33-158 MPa, Young modülleri ise 16-99 GPa ve 5-57 GPa arasında değişmektedir. Ayrıca magmatik kayaların eksenel yükler altındaki gevrek kırılma türündeki yenilmeleri gerilme-şekil değiştirme diyagramlarında oldukça belirgindir. İstanbul'da başta tüneller olmak üzere yeraltı kaya yapılarında karşılaşılan problemlerin tümü dikkate alındığında; yan kayaçlar ile daykların dayanım ve deformasyon özelliklerindeki farklılıkların en önemli jeolojik sorunlardan biridir. Bu çalışmadaki bulgular, bölgedeki yeraltı kaya yapılarının inşa aşamaları ve özelikle uzun dönem performansları için ayrıntılı jeomekanik araştırmaların gerekliliğini ortaya koymaktadır.

Anahtar Kelimeler: Gevreklik, Dayk, Elastik Özellikler, Jeomekanik Özellikler, İstanbul 
Ündül, Çobanoğlu, Taz

\section{ABSTRACT}

The enlargement of settlement areas due to increasing population emerges the construction of infrastructural and other engineering structures. The construction of engineering structures has been densely continued from the second half of the 1900's to the present in Istanbul. Many engineering projects are being planned for the near future. The recent structures are larger and deeper than the previous structures. Thus, the planners and engineers have faced to more geo-engineering problems related with geological uncertainties. In recent years, majority of the engineering structures in Istanbul are getting denser in the Paleozoic sequence of Istanbul along both the two sides of the Bosphorus. The Paleozoic sequence of Istanbul mostly consists of sedimentary rocks. These sedimentary rocks are crosscut by dikes with varying compositions, in random orientation and dimensions (e.g. millimeter to couple of meter in scale). The dike crosscutting the Istanbul Paleozoic rocks generate unexpected and unwanted conditions such as squeezing of TBMs, stability problems, water leakage etc. As a result, increase in time and budget of the projects occur. This study aims to define the strength and deformation properties of dikes in Istanbul under axial loadings. Besides, the brittleness of the studied rocks and their engineering behavior in practical applications were evaluated. In addition, the behavior of dikes and host rocks were compared regarding basic rock mass properties. Based on the test results, the uniaxial compressive strength and Young's modulus of dikes and the host rocks are determined as 46-277MPa and 33-158 MPa, and 16-99 GPa and 5-57 GPa, respectively. Besides, the brittle failure of the magmatic rocks under axial loadings is obvious in the graph of strength versus strain. Once the problems encountered particularly in tunnel constructions in Istanbul are evaluated, it is defined that the differences between the strength and strain characteristics of host rocks and dikes become an important geological problems. The results of this study state necessitate the detailed geo-mechanical investigations during the construction and for the longterm performance of underground rock structure.

Keywords: Brittleness, Dike, Elastic Properties, Geomechanical Properties, İstanbul

\section{GÍRIŞ}

Dünya'nın en büyük şehirlerinden biri olan İstanbul'un hem nüfusu hem de yerleşim alanı gereksinimi hızı bir şekilde artmaktadır. $\mathrm{Bu}$ artışa paralel olarak pekçok yeraltı yapısı inşa edilmekte ve planlanmaktadır. $\mathrm{Bu}$ mühendislik projeleri, İstanbul'un Avrupa ve Anadolu yakalarında çeşitli boyutlarda yayılım gösteren Paleozoyik, Mesozoyik ve Senozoyik birimler üzerinde ve içerisinde yer almaktadır. Jeolojik birimler üzerinde uzun yıllardan beri ayrıntılı çalışmalar yürütülmüştür (Tchihatcheff, 1864; Penck, 1919; Ketin, 1941; Kaya, 1973; Önalan, 1981 ve 1982; Özgül, 2012; Y1ldırım vd., 2013). Özellikle son 20-25 yıl içerisinde söz konusu mühendislik faaliyetleri genellikle İstanbul Boğazı'nın iki yakasında, İstanbul Paleozoik istifi içerisinde yoğunlaşmaktadır. Buna koşut olarak, Paleozoik istifi pek çok yerde kesen daykların inşaat faaliyetlerine etkileri de sıklıkla rapor edilmektedir.

İstanbul'daki farklı köken ve bileşimdeki daykların varlığı bölgede yapılan ilk çalışmalardan itibaren bilinmektedir (Penck, 1919; Okay, 1948). İstanbul'daki mühendislik projelerinin tür ve miktarlarının, derinliklerinin ve proje boyutlarının artması araştırmacıların ve mühendislerin daha fazla dayk - yan kaya ilişkisiyle karşılaşmasına neden olmaktadır. Özellikle yeraltı kaya yapılarında karşılaşılan dayklar pekçok alanda taze ve az ayrışmış olarak gözlenmektedir. Yeraltı mühendislik çalışmalarında, dayk - yan kaya ilişkisinde, kaya ve kaya kütle özelliklerindeki ani değişimler nedeniyle, tünel kazı makina ve ekipmanlarının beklenenden çabuk aşınması, TBM sıkışmaları, duraysızlık vb. sorunlar anlatılmaktadır (Dalgıç, 2000 ve 2002; Biberoğlu, 2006; Varol ve 
Dalgıç, 2006; Bilgin vd., 2008; Fugro, 2010; Eyigün, 2014; Bilgin vd., 2016). Buna ek olarak, Kaiser ve Cai (2012), yan kayalara göre daha dayanımlı olan daykların yeraltı kazıları sırasında özellikle uzun dönemde gerilme artışlarına neden olabileceği ve olumsuz gerilme koşulları yaratabileceğini belirtmişlerdir. Ayrıca Bilgin (2016) daykların varlığının tünelcilik faaliyetlerinin uzun sürmesine neden olan önemli jeolojik etmenlerden olduğunu belirtmiştir.

Şimdiye dek yapılan çalışmalarda İstanbul Paleozoyik istifini kesen daykların jeomekanik özelliklerinin literatürde yer almadığ 1 fark edilmiştir. Bu çalışmada, İstanul Paleozoik istifini kesen ve farklı bölgelerden alınan farklı bileşimlerdeki daykların ve yan kayaçların jeomekanik özellikleri birlikte değerlendirilecektir. $\mathrm{Bu}$ bağlamda, kayaçların birim ağırlıkları ve porozitelerini de içeren fiziksel özellikler belirlenmiştir. Tek eksenli sıkışma dayanımı deneyleri yüksek hassasiyetli şekil değiştirme ölçümleriyle birlikte gerçekleştirilmiştir. $\mathrm{Bu}$ ölçümler sonucunda, Young Modülü ve Poisson oranları hesaplanmıştır. Kristalli kayaçların yeraltı kazılarındaki uzun dönem performanslarının belirlenmesinde (Damjanac ve Fairhurst, 2010) ve kavlaklanma analizlerinde (Nicksiar ve Martin, 2013) önemli bir veri olarak kullanılan çatlaklanma başlangıcı gerilme seviyeleri belirlenmiştir. Bunlara ek olarak, kayaçların akma sinırlarında veya hemen sonrasinda yenilmeleri olarak tanımlanan gevreklikleri de (Hetenyi, 1966; Hucka ve Das, 1974; Meng vd., 2015) bu çalışma kapsamında değerlendirilmiştir. Kayaların gevreklikleri, TBM kazılarında kazıcı uçların kayada oluşturduğu çatlakların gelişimini ve ezilen kesimin boyutlarını etkilemektedir. Böylece kazıcı uçların daha yüksek kazı etkisi oluşturmasına izin vermektedir (Gong ve Zhao, 2007). Benzer şekilde çatlakların gelişimini etkileyen gevreklik özelliği hidrolik çatlatma ile yapılan hidrokarbon üretimlerinde de etkinliği arttırmaktadır (Zhishui ve Zandong, 2015). Bu kapsamda, gevrekliğin TBM kazıcı uçlarına, yeraltı kaya yapılarındaki kazı performansına (Blindheim ve Bruland, 1998; Kahraman, 2002; Gong ve Zhao, 2007; Yağ1z, 2009; Ko vd., 2016), kavlaklanma değerlerinin belirlenmesine (Diederichs vd., 2004; Lee vd., 2004) ve hidrolik çatlatmaya (Zhishui ve Zandong, 2015; Holt vd., 2015) etki yaptığı ifade edilmiştir. Hajiabdoulmajid ve Kaiser (2003) ise, kayaçların gevrekliklerinin yeraltı kaya yapılarının uzun ve kısa dönemdeki duraylılıklarına ve aşırı sökülme alanlarının şekillerinin belirlenmesindeki önemine vurgu yapmışlardır. Meng vd. (2015)'de gevrekliğin kaya davranışının izlenmesinde ve destek sistemlerinin belirlenmesinde önemli bir parametre olduğunu belirtmiştir. $\mathrm{Bu}$ nedenlerden dolayı, gevreklik ve kavlaklanma değerlerinin belirlenmesi için Brazilian dolaylı çekme ve tek eksenli sıkışma deneyleri aynı örnek grupları için gerçekleştirilmiştir.

Yukarıdaki çalışmalara ek olarak, mineralojik bileşimlerin belirlenmesi için X 1şını kırınım analizleri yapılmıştır. Ayrıca, örneklerin ince kesitleri yapılarak polarizan mikroskopta petrografik özellikleri belirlenmiştir. Araştırma sirasında benzer fiziksel ve mekanik deneyler, daykların içlerine sokulum yaptığı yan kayaçlarda da gerçekleştirilmiştir. Ayrıca, daykların ve yan kayaçların dayanım ve deformasyon özellikleri değerlendirilmiştir.

İstanbul'da, tüneller başta olmak üzere pekçok mühendislik girişiminin (derin kazılar, şevler vb.) yapımları ve planlamaları hızlı bir şekilde artmaktadır. Bu çalışmada sunulan veriler ve tartışılan konular, daykların ve yan kayaların jeomekanik özelliklerinin anlaşılmasına katk1 yapacağı gibi söz konusu kayaçların birlikte yer 
aldıkları jeolojik ortamlarda meydana gelebilecek sorunların anlaşılmasına da katkı sağlayacaktır.

\section{ÇALIŞMA ALANININ JEOLOJISİ}

Ordovisiyen'den Permiyen'e kadar kesintisiz 1000m'den fazla kalınlığa sahip Paleozoik istif, İstanbul'da çok geniş alanlar kaplamaktadır (Şekil 1). Bu istif genel olarak yanal ve düşey geçişlidir ve farklı fasiyeslerdeki kırıntılı ve karbonatlı kayalardan oluşmaktadır. Yer yer kireçtaşı mercekleri karakteristik olarak gözlenmektedir (Önalan, 1981 ve 1982;
Eroskay, 1985). İstanbul Paleozoyik istifi Geç Karbonifer'de ve Geç Mesozoik’te kıvrımlanmış ve istif içinde bindirme fayları gelişmiştir. $\mathrm{Bu}$ birim, Permiyen-Triyas çökelleri tarafından örtülmektedir (Önalan, 1981 ve 1982).

Farklı mühendislik çalışmalarındaki kazılar ve İstanbul'un her iki yakasında yapılan sondajlar daykların geniş ve sık yayılımını ortaya koymaktadır. Bölgedeki dayklar genel olarak 58.9-72.5 My yaş aralığında olup andezit, diyabaz, dasit, lamprofir vb. bileşimlerdedir (Aysal vd., 2015).

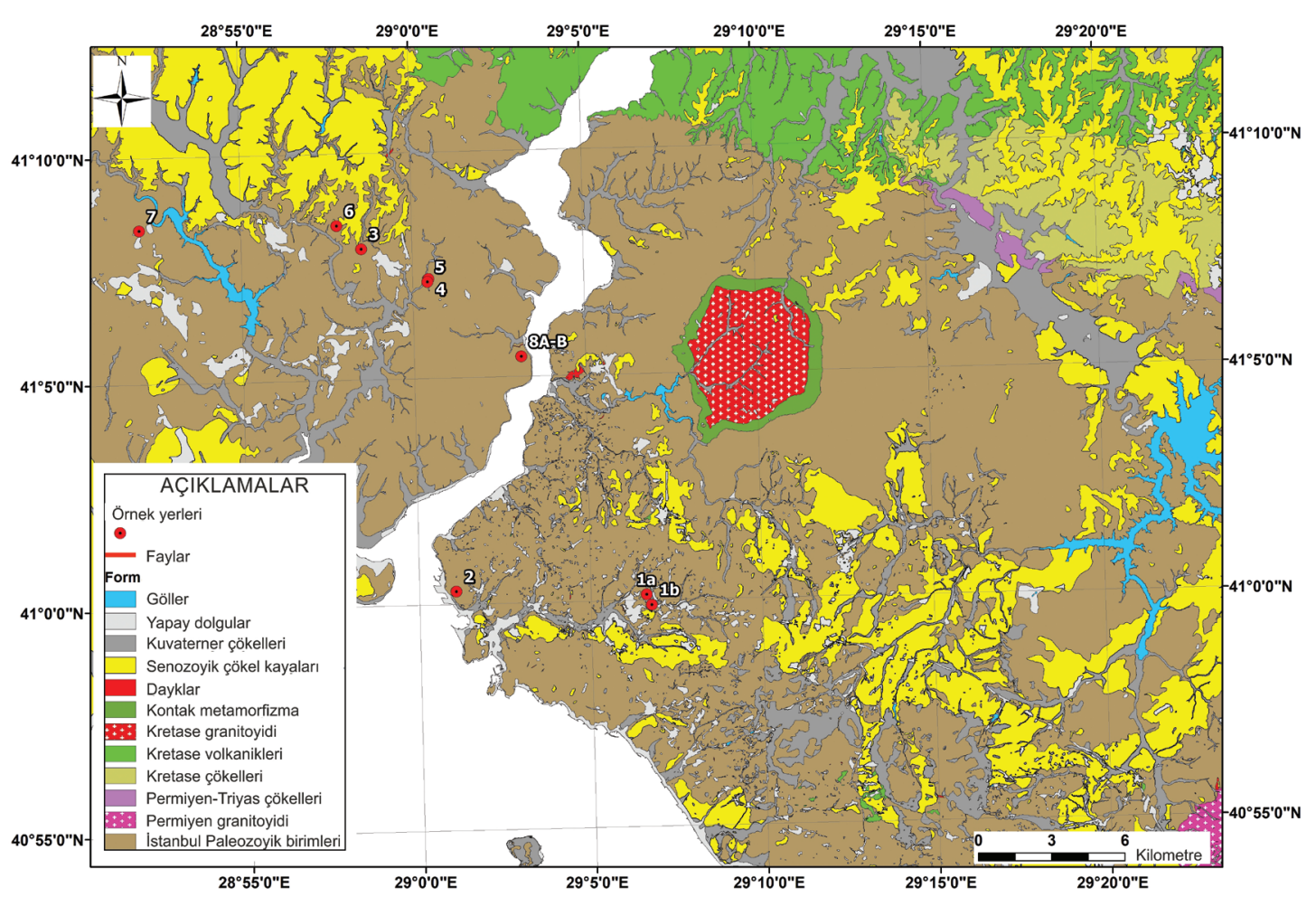

Şekil 1. İstanbul'un sadeleştirilmiş jeoloji haritası üzerinde örnek yerlerinin gösterimi (Jeoloji haritası İBB, 2011'den sadeleştirilmiştir).

Figure 1. Sampling locations shown on the simplified geological map of Istanbul (Simplified from IBB, 2011). 


\section{ÖRNEKLERIN TANIMLANMASI VE DENEY YÖNTEMLERİ}

\section{Örnekleme ve Örneklerin Tanımlamaları}

$\mathrm{Bu}$ çalışmada kullanılan dayk örnekleri sondajlardan ve araziden alınan en az $50 \times 50 \times 50 \mathrm{~cm}$ boyutlarındaki bloklardan karot alınmasıyla elde edilmiştir. Blokların ve karotların dış etkilerden uzak kalmasına özen gösterilmiştir. İncelenen dayklar genel olarak felsik (örneğin dasit ve andezit) ve mafik (örneğin lamprofir ve diyabaz) bileşimlidir. Tortul olan yan kayaçları genelde kumtaşı, çamurtaşı, silttaşı ve kireçtaşlarından oluşmaktadır (Şekil 2). Çizelge 1 ve Şekil 1 örnekleme noktalarını ve yan kayalar hakkında verilen temel bilgileri göstermektedir.
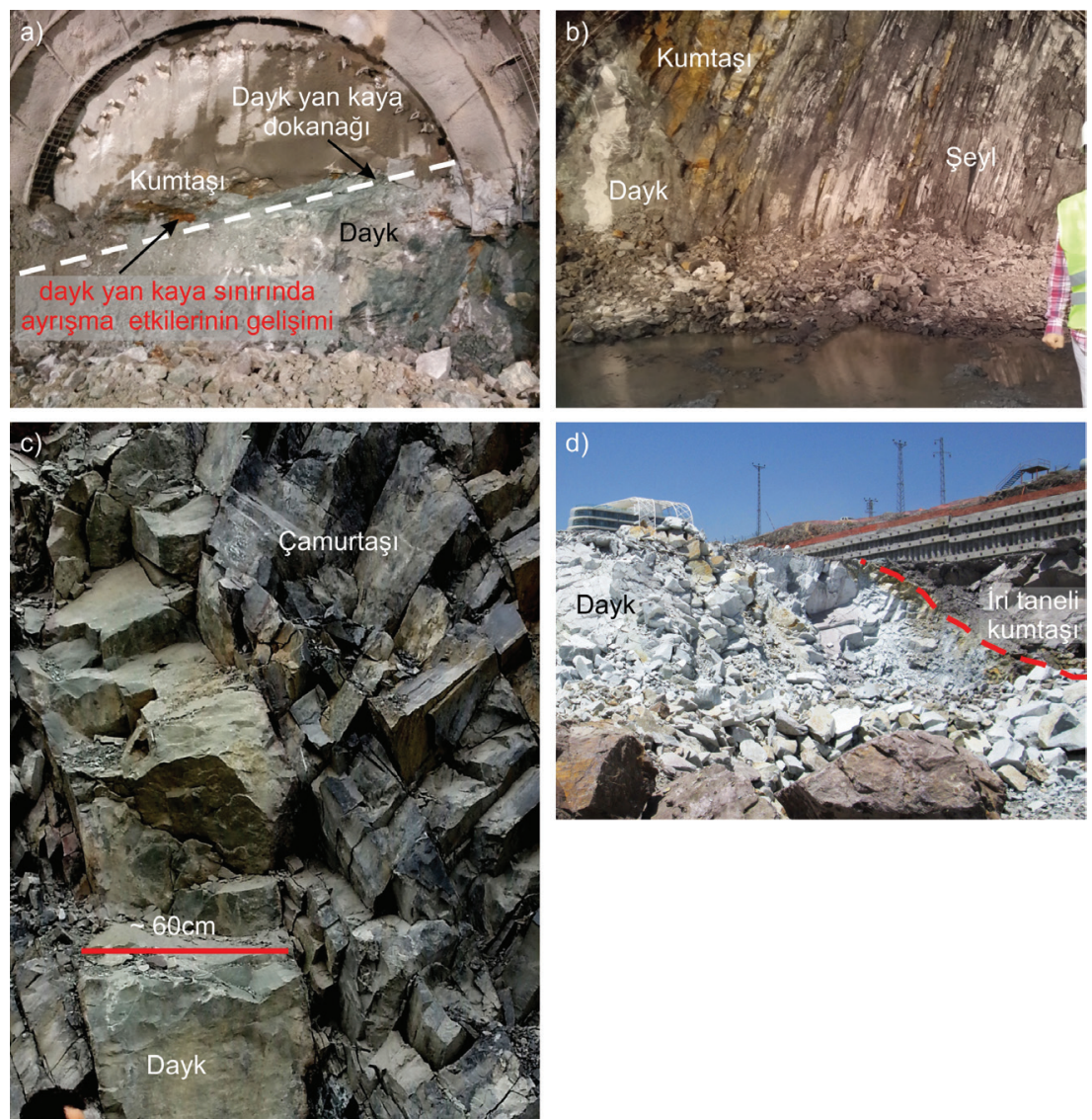

Şekil 2. Farklı mühendislik çalışmalarında daykların görünümü a) tünel aynasının alt kısmında dayk görünümü ve hemen üzerinde çoğunluğu püskürtme beton ile kaplanan kısımda kumtaşları yer almaktadır. Ayrıca dayk - kumtaşı sınırı boyunca ayrışma etkilerinin geliştiği belirgindir, b) Avrasya Tüneli kara tarafında dayk ve yan kayaç görüntüsü, c) taş ocağı şevlerinde çamurtaşı içerisinde sokulmuş lamprofir bileşimli dayk görüntüsü, d) bir temel kazısında andezit bileşimli daykların iri taneli kumtaşlarını kestiği alana ait görünüm.

Figure 2. Views of dikes from varying engineering studies a) a view of dike in the lower section of the tunnel and above is the sandstone that is mostly covered by shotcrete. Besides weathering effect along the boundary of dikesandstone is evident, b) view of dike and host rock in the land side excavation of the Eurasia Tunnel, c) a view of lamprophyre dike within the mudstones along the slopes of a quarry, d) a view of andesitic dikes cross-cutting the coarse grained sandstones in a foundation. 
Çizelge 1. Çalışılan kayaçların genel özellikleri ve örnekleme yerleri.

Table 1. General properties and sampling locations of the studied rocks.

\begin{tabular}{|c|c|c|c|}
\hline Örnek yeri & Petrografik tanım & Örnek türü & Yan kayaç \\
\hline $1 \mathrm{~A}-1 \mathrm{~B}$ & $\begin{array}{l}\text { 1A Lamprofir } \\
\text { 1B Andezit }\end{array}$ & Temel kazısı & İnce taneli kumtaş1 - iri taneli kumtaşı \\
\hline 2 & Lamprofir & Tünel & Kumtaş1 - şeyl, yumrulu kireçtaş1 \\
\hline 3 & Lamprofir & Taş ocağ1 & Kumtaşı - şeyl ardalanması \\
\hline 4 & Lamprofir & Temel kazısı & Kumtaş1-çamurtaşı \\
\hline 5 & Lamprofir & Taş ocağ1 & Kumtaş1-çamurtaş1 \\
\hline 6 & Lamprofir & Taş ocağ1 & Çamurtaşı \\
\hline 7 & Diyabaz & Taş ocağ1 & Çamurtaşı \\
\hline $8 \mathrm{~A}-8 \mathrm{~B}$ & $\begin{array}{l}\text { 8A Lamprofir } \\
\text { 8B Andezit }\end{array}$ & Sondaj & Kireçtaş1 \\
\hline
\end{tabular}

Ayrışmanın etkisiyle kayaçlarda mikrosüreksizliklerin sayısının arttı̆̆1 bilinmektedir (Arıkan vd., 2007). Bu çalışmada incelenen kayalar taze - az ayrışmış seviyelerden alındığ 1 için ayrışmaya bağlı süreksizlikler sınırlıdır. İncelenen dayklar orta-geniş aralıklı $(20 \mathrm{~cm}-$ $2 \mathrm{~m})$ süreksizlik içeren kaya kütleleridir. Diğer taraftan, dayklar oluşumları itibariyle yan kayaçlara göre oldukça gençtirler. Bölge iki büyük orojenik hareketten etkilenmesine karşın, dayklar sadece daha geç evrede gelişen tektonik olaylardan etkilenmiştir. $\mathrm{Bu}$ nedenle, dayk kütleleri yan kayaçlarına göre daha az süreksizlik içermektedirler. Sürekizlikler çoğunlukla kapalı, yer yer kalsit dolguludur.

\section{Mineralojik ve Petrografik Çalıșmalar}

Dayk örneklerinin mineralojisi rastgele yönlendirilmiş toz örnekler üzerinde $X$ 1şını kırınımı analizleriyle değerlendirilmiştir. Örnekler kırıldıktan sonra ögütülmüş ve temsili kısımları $\mathrm{Cu}(\mathrm{K} \alpha)$ radyasyonu altında oda sıcaklığında 5 - $55^{\circ} 2 \theta$ aralığında taranmıştır.
52 ince kesit üzerinde mikroskop çalışmaları gerçekleştirilmiştir. Mekanik deney yapılan her bir karot örneğinden ince kesit alınmıştır. İnce kesit görüntüleri Leitz Orthoplan mikroskoplarda Leica Görüntüleme sistemiyle elde edilmiştir.

\section{Fiziksel Özelliklerin Belirlenmesinde İzlenen Yöntemler}

İncelenen dayklara ait birim hacim ağırlıklar $(\gamma)$, etkin porozite $\left(n_{t}\right)$ ve $P$ dalga hızını $\left(V_{p}\right)$ içeren fiziksel özellikler ISRM (1981 ve 2007) standartlarına göre belirlenmiştir. Mekanik deneyler öncesinde $\mathrm{P}$ dalga hızı ölçümleri Proceq Pundit Lab marka cihaz kullanılarak kuru koşulda yapılmıştır.

\section{Mekanik Deneyler, Gevreklik ve Kavlaklanma Analizleri}

Tek eksenli sıkışma dayanımı (UCS) ve Brazilian dolaylı çekme dayanımı (BTS) deneyleri servo-hidrolik kontrollü deney cihazı yardımıyla, yüksek hassasiyetli düşey 
ve yanal şekil değiştirme ölçerlerle birlikte gerçekleştirilmiştir. Karot örnekleri UCS ve BTS deneyleri için önce testereyle kesilmiş ardından paralelliklerinin sağlanması için hassas aşındırma işlemi yapılmıştır. Karot örneklerinin boy-çap oranı UCS örnekleri için 2, BTS örnekleri için ise 0.5 olarak alınmıştır. Örneklerin alt ve üst yüzeylerinin paralelliği ISRM (1981 ve 2007)'de önerilen standartlara uygun olacak şekilde hazırlanmıştır. Her örneğe ait BTS değerleri Eşitlik 1 yardımıyla belirlenmiştir.

$\mathrm{s}_{t}=\frac{2 F}{\mathrm{p} D}$

$\mathrm{F}=$ Yenilme anındaki yük $(\mathrm{kN})$

$\mathrm{D}=$ Örneğin çap1 (mm)

$\mathrm{L}=$ Örneğin kalınlığ $(\mathrm{mm})$

$\mathrm{Bu}$ çalışmalara ek olarak, tek eksenli sıkışma dayanımı deney verileri önemli bir kaya parametresi olan çatlaklanma başlangıcı gerilme seviyelerinin $\left(\sigma_{\mathrm{c}}\right)$ (Bieniawski, 1967; Damjanac ve Fairhurst, 2010; Nicksiar ve Martin, 2013) belirlenmesinde kullanılmıştır. $\mathrm{Bu}$ analizlerde Lajtai (1974) tarafından önerilen yöntemden yararlanılmıştır. $\mathrm{Bu}$ çalışmada elde edilen gerilme seviyeleri gevrek kayaların kavlaklanma gerilme seviyelerini ortaya koymasindan dolayı kavlaklanma analizleri olarak da ifade edilmektedir (Diederichs vd., 2004). Kayaların çatlaklanma başlangıcı gerilme seviyeleri tek eksenli sıkışma dayanımlarının yaklaşık 0.3-0.7 seviyelerindedir (Bieniawski, 1967; Nicksiar ve Martin, 2013). Bu bağlamda, söz konusu gerilme seviyeleri her bir kaya için ancak tek eksenli sıkışma dayanımı deneyi ile tespit edilmektedir.

Kayaların gevrekliklerinin belirlenmesi için pekçok sayısal yaklaşım önerilmiştir. Kayaların gevrekliklerinin belirlenmesi için önerilmiş yöntemler Andreev (1995). Meng vd.
(2015) ve Xia vd. (2017) tarafından derlenmiş ve değerlendirilmiştir. Heidari vd. (2014) ve Meng vd. (2015) aşağıda verilen eşitliklerin (Eşitlik 2 ve 3) gevrekliğin tespitinde en sik kullanılan yöntemler olduğunu belirtmişlerdir. Ayrica, Lee vd. (2004) ile Diederichs vd. (2004) kavlaklanma ve kaya patlamalarının UCS/ BTS oranına göre değerlendirilebileceğini belirtmişlerdir. Önceki araştırmacılar UCS/BTS oranının artmasıyla gevrekliğin arttığına işaret etmişlerdir. Ancak gevreklik mertebesinin ifade edilebileceği literatürde yaygın kullanımı olan bir sinıflama önermemişlerdir. Bu nedenlerden dolayı bu çalışmada, Eşitlik 2 ve 3 kullanılarak çalışılan kayaların gevreklikleri hakkında bilgi edinilmeye çalışılmış ve Eşitlik 2 yardımıyla da az-orta derecede süreksizlik içeren bu kayalara ait kavlaklanma analizlerine katkı sağlanmıştır.

$$
\begin{array}{ll}
B_{1}=\frac{\mathrm{S}_{c}}{\mathrm{~S}_{t}} & \text { (2) (Hucka ve Das, 1974) } \\
B_{2}=\frac{\mathrm{S}_{c} x \mathrm{~S}_{t}}{2} & \text { (3) (Altındağ, 2000) }
\end{array}
$$

$\sigma_{c}$ Tek eksenli sıkışma dayanımı

$\sigma_{t}$ Brazilian dolaylı çekme dayanımı

\section{BULGULAR}

\section{Mineralojik ve Petrografik Veriler}

Petrografik çalışmalardan elde edilen verilere göre çalışılan dayklar lamprofir, diyabaz ve andezit bileşimlerindedir. Lamprofir bileşimli (koyu renkli çoğunlukla ortoklaz ve amfibolden oluşan, panidiyomorfik doku gösteren bir damar kayacı) dayklar genelde yeşil, koyu yeşil renklerdedir ve plajiyoklaz fenokristalleri ve kloritler belirgindir. Plajiyoklaz kristallerinin boyutları $1 \mathrm{~mm}-3 \mathrm{~mm}$ arasında değişmektedir 
(Örneğin örnek yeri 1A, 2, 4, 6, 8A, Şekil 3). Bazı örnek yerlerinde daha küçük kristaller, nadiren sparitik damarlar ve amfibollere rastlanmıştır (Örneğin örnek yeri SL 3, 8 A, Şekil 3 ve Şekil 4). Hamur malzemesinde karbonatlaşma ve klorit gelişimi karakteristiktir.

Diyabaz bileşimli dayklar da koyu yeşil renkleriyle belirgindir (Örneğin örnek yeri 7). Feldspat fenokristalleri belirgin olup yer yer plajiyoklaz mikrolitlerine ve iri kristallere koritleşmiş hamur içerisinde rastlanır. Alterasyona bağlı kil ve karbonat oluşumu gelişmiştir. Yer yer sparitik damarlar belirgindir.

Ataşehir ve Levent bölgelerinde (Örneğin örnek yerleri 1B ve 8B) beyaz gri renkli andezit bileşimli dayklara rastlanmıştır. Mineraller gözle görülebilecek şekildedir. Feldspat kristalleri örneklerin büyük kısmını kapsamakta olup boyutları 1-5mm arasındadır. Amfibol ve biyotit mineralleri daha az oranda gözlenmektedir. Ayrıca Levent bölgesindeki dayklarda klorit ve epidot damarları vardır (Örneğin örnek yeri 8B). (Çizelge 2, Şekil 3 ve Şekil 4).

Çizelge 2. XRD çalışmalarına göre dayk örneklerinin mineral bileşimleri.

Table 2. Mineralogical assemblages of the dikes according to XRD studies.

\begin{tabular}{cc}
\hline $\begin{array}{c}\text { Örnek } \\
\text { Yeri }\end{array}$ & Mineral bileşimi \\
\hline 1A & Plajiyoklaz, amfibol, klorit \\
1B & Plajiyoklaz, kuvars, klorit, montmorillonit \\
2 & Plajyoklaz, klorit, flogopit, kuvars \\
3 & Plajyoklaz, klorit, flogopit, kuvars, kalsit, \\
4 & amfibol \\
5 & Plajyoklaz, kuvars, klorit \\
6 & Albite, plajyoklas, klorit, kuvars \\
7 & Plajyoklaz, klorit, piroksen \\
8A & Plajyoklaz, amfibol, klorit \\
8B & Plajyoklaz, kuvars, klorit \\
\hline
\end{tabular}

İncelenen kayalara ait XRD analizleri yardımıyla belirlenen mineral içerikleri Çizelge 2'de sunulmuştur. Çalışılan örneklerde albit, amfibol ve kloritlerin baskın mineraller olduğu gözlenmektedir (Çizelge 2).
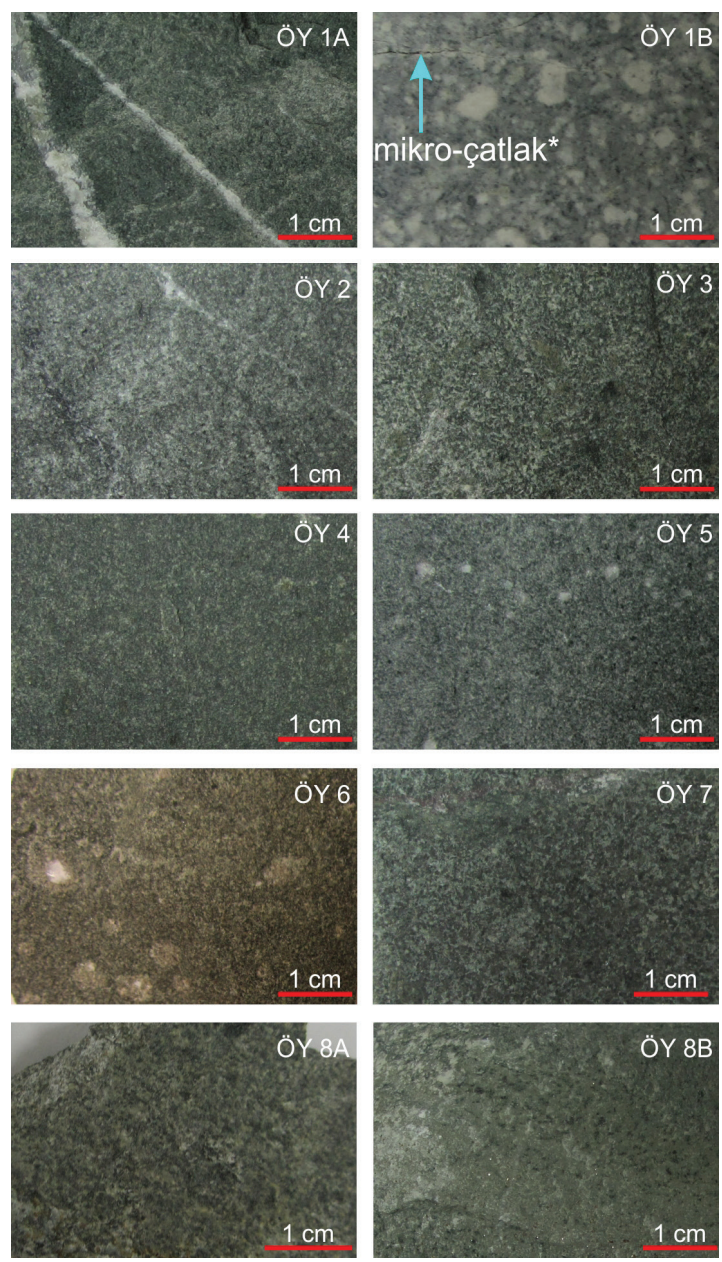

Şekil 3. Çalışılan kayaçların el örneklerinin yakından görünümleri.

(* karot alma işlemi öncesinde tespit edilemeyen mikro çatlak)

Figure 3. Macroscopic views of hand specimens of the studied rocks.

$(*$ microcrack which can not be detected before coring process) 

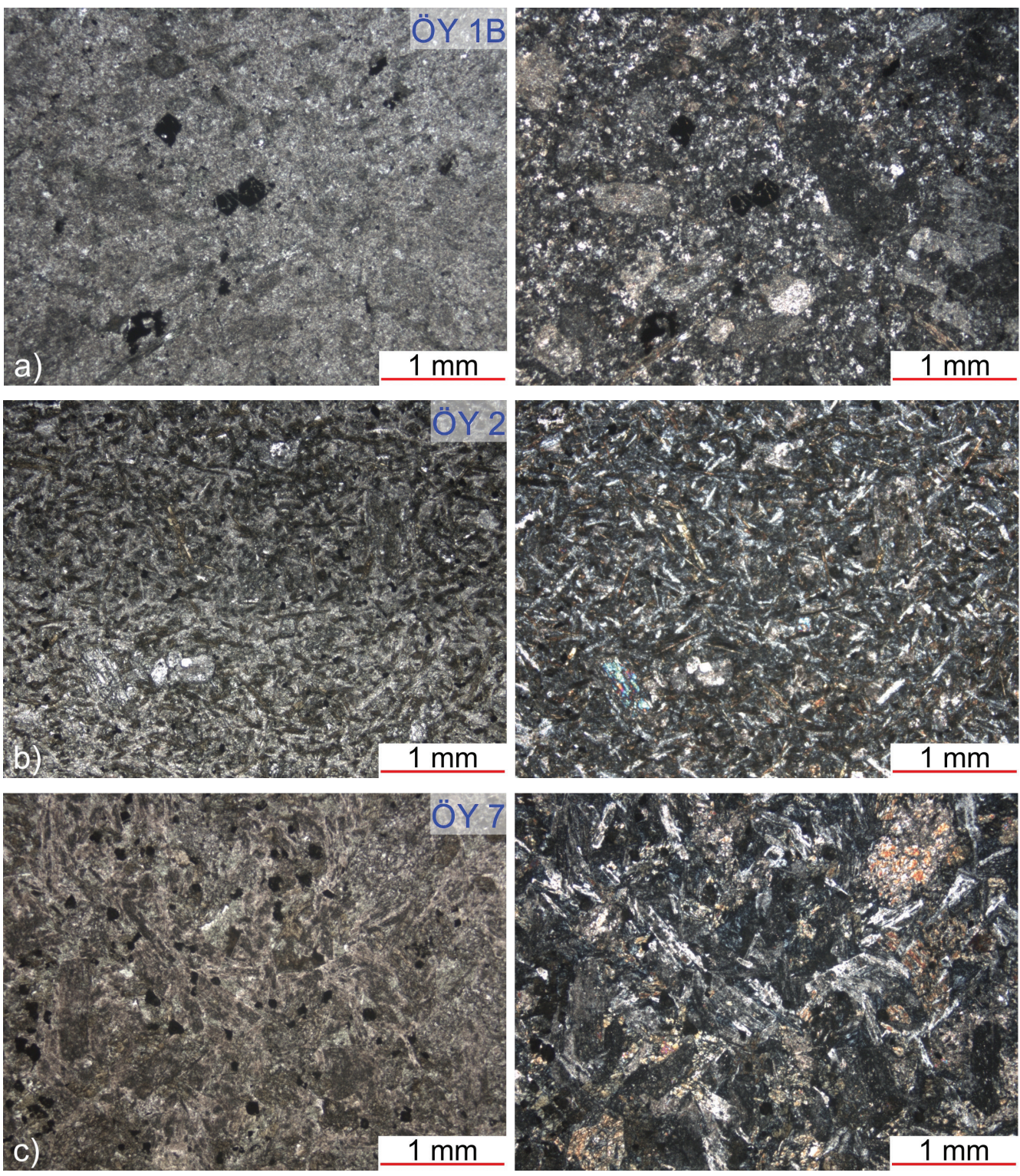

Şekil 4. Daykların mikroskop altındaki görüntüleri a) andezit bileşimli örnek, b) lamprofir bileşimli örnek, c) diyabaz bileşimli örnek.

(Mikroskop görüntülerinde sol taraftaki görüntüler tek nikol sağ taraftaki görüntüler ise çift nikol görüntüleridir)

Figure 4. Photomicrographs of dikes a) dikes with andesitic composition, $b$ ) sample of lamprophyre composition, $c$ ) sample of diabase composition.

(The views on left were obtained by parallel nicols and views on right were obtained by cross nicols) 


\section{Daykların Fiziksel ve Mekanik Özellikleri}

Deneye tabi tutulan örneklere ait fiziksel özellikler (örneğin $\gamma, \mathrm{n}_{\text {eff }} ; \mathrm{V}_{\mathrm{p}}$ ) Çizelge 3 'te, tek eksenli sıkışma ve Brazilian dolaylı çekme dayanımları, Young Modülü ve Poisson oranı değerleri Çizelge 4'te özetlenmiştir.

Daykların birim hacim ağırlıkları 24.14 ile $29.08 \mathrm{kN} / \mathrm{m}^{3}$ arasında değişmektedir. Genelde düşük porozite değerleri olan örnekler (\% 0.28 \% 4.65), 3.90-6.69 km/s arasında değişen P-dalga hızlarına sahiptirler (Çizelge 3). Daykların tek eksenli sıłışma dayanımları 46-277 $\mathrm{MPa}$ arasındadır. Eksenel şekil değiştirme grafiğinden elastisite modülleri 16-99 $\mathrm{GPa}$ aralığında, aynı seviyedeki Poisson oranı ise 0.04-0.28 aralığında elde edilmiştir (Çizelge 4).

İncelenen kayalar içerisinde en düşük birim hacim ağırlıklar andezit bileşimli örneklerden elde edilmiştir (Örneğin örnek yeri 1B). Ayrıca ÖY 1B andezitleri ile ÖY 2 lamprofirleri nispeten daha yüksek poroziteye sahiptirler. En yüksek Young modülü değerleri ÖY 7'deki diyabazlardan elde edilmiştir ve bu kaya grubu en yüksek Poisson oranına da sahiptir. Çalışılan kayalar içerisinde en yüksek tek eksenli sıkışma dayanımları ise lamprofir dayklarına ait ÖY 5 ve ÖY 6 'dan elde edilen elde edilmiştir (Çizelge 4).

Çizelge 3. Çalışılan daykların fiziksel özellikleri.

Table 3. Physical properties of the studied dikes.

\begin{tabular}{cccc}
$\begin{array}{c}\text { Örnek } \\
\text { Yeri }\end{array}$ & $\gamma\left(\mathrm{kN} / \mathrm{m}^{3}\right)$ & $\mathrm{n}_{\text {etkin }}$ & $\mathrm{V}_{\mathrm{p}}(\mathrm{km} / \mathrm{s})$ \\
\hline 1A & $26.14-26.37-26.72$ & $0.86-1.01-1.19$ & $3.93-5.39-5.97$ \\
1B & $24.14-24.32-24.88$ & $2.26-2.72-3.31$ & $4.3-4.8-5.32$ \\
2 & $26.86-27.16-27.64$ & $3.11-3.99-4.65$ & $4.4-4.73-5.4$ \\
3 & $27.4-27.6-27.6$ & $1.03-1.58-2.04$ & $4.7-5.41-5.71$ \\
4 & $28.24-28.37-28.42$ & $0.52-0.53-0.54$ & $6.21-6.44-6.69$ \\
5 & $26.67-26.92-27.06$ & $1.2-1.6-1.9$ & $3.9-4.3-5.1$ \\
6 & $27.28-27.47-27.62$ & $0.53-0.76-1.07$ & $5.87-5.98-6.15$ \\
7 & $28.09-28.3-28.5$ & $0.28-0.31-0.33$ & $5.57-5.63-5.73$ \\
$8 \mathrm{~A}$ & $28.80-28.94-29.08$ & $1.01-1.29-1.54$ & $4.72-5.08-5.4$ \\
$8 \mathrm{~B}$ & $27.5-27.8-28.1$ & $1.13-1.22-1.31$ & $5.03-5.13-5.24$ \\
\hline
\end{tabular}

Deney sonuçlarında sırasıyla en düşük, ortalama ve en yüksek değerler sunulmuştur.

Çizelge 4. Çalışılan dayklara ait mekanik deney sonuçları ve gevreklik değerleri.

Table 4. Mechanical properties and brittleness values of the studied dikes.

\begin{tabular}{cccccccc}
\hline $\begin{array}{c}\text { Örnek } \\
\text { Yeri }\end{array}$ & $\mathrm{E}(\mathrm{GPa})$ & $v(-)$ & $\sigma(\mathrm{MPa})$ & $\sigma_{C I, \text { cap }}(\mathrm{MPa})$ & $\mathrm{BTS}(\mathrm{MPa})$ & \multicolumn{2}{c}{ Gevreklik değerleri } \\
\hline 1A & $24-45-55$ & $0.07-0.11-0.15$ & $69-169-244$ & $25-54-77$ & $9.4-12-17$ & $13-14.5-15.5$ & $686-1117-2025$ \\
1B & $16-25-31$ & $0.04-0.07-0.1$ & $46-95-177$ & $19-30-57$ & $5.6-7.25-8.9$ & $21.6-28.6-35.6$ & $338-874-1410$ \\
2 & $22-27-34$ & $0.06-0.07-0.09$ & $113-158-186$ & $33-46-57$ & $10.2-10.8-11.4$ & $11-14-16$ & $852-576-1060$ \\
3 & $40-41-43$ & $0.09-0.09-0.1$ & $86-175-222$ & $25-53-67$ & $9-11.5-14.9$ & $9.6-14.9-17.4$ & $387-1050-1676$ \\
4 & $46-47-49$ & $0.08-0.1-0.12$ & $130-240-277$ & $44-69-81$ & $8-9.1-11.2$ & $25-29-32$ & $1016-1230-1562$ \\
5 & - & - & $105-136-151$ & - & $10.3-13.5-16.3$ & $9.3-10-10.8$ & $540-938-1230$ \\
6 & $40-41-44$ & $0.08-0.09-0.11$ & $186-194-201$ & $53-55-56$ & $6.8-8.8-11.5$ & $17.5-23-27.4$ & $632-852-1155$ \\
7 & $82-92-99$ & $0.26-0.27-0.28$ & $155-165-173$ & $59-65-72$ & $8.4-12-15$ & $11.7-14.4-19$ & $654-1010-1280$ \\
8A & 42 & 0.11 & $97-100-103$ & 34 & 8.8 & 11.02 & 426 \\
8B & 26 & 0.1 & $103-113-123$ & 37 & 11.2 & 10.98 & 688 \\
\hline
\end{tabular}

İlgili alanlarda sırasıyla en düşük, ortalama ve en yüksek değerler sunulmuştur. Gevreklik değerleri tek eksenli sıkışma dayanımı ve brazilyan çekme dayanımı deney sonuçları olan örnekler üzerinde gerçekleştirilmiştir. 


\section{Yan Kayaçların Fiziksel ve Mekanik Özellikleri}

İncelenen dayklar her örnek noktasında Paleozoik'e ait sedimenter kayaçları kesmektedir. Araştırma sırasında yan kayaçlardan yöntemler kısmında tanımlandığı gibi örnekler alınmıştır. Çizelge 5'te yan kayaçlara ait fiziksel (birim hacim ağırlık, etkin porozite, P dalga hızı) ve mekanik (tek eksenli sıkışma dayanımı, çekme dayanımı, elastisite modülü, poisson oranı) özellikler sunulmuştur.

Yan kayaçların birim hacim ağırlıkları 24.1 ile $27.4 \mathrm{kN} / \mathrm{m}^{3}$ arasında değişmektedir. Ölçüm yapılan yan kayaç örneklerinde porozite değerleri farklılık göstermekte olup \%0.05-6.8 arasında değişmektedir. P-dalga hızları 2.5-6.8 $\mathrm{km} / \mathrm{sn}$ arasında olan yan kayaçların tek eksenli sıkışma dayanımları ise 28-158 MPa arasındadır. Eksenel şekil değiştirme grafiğinden elastisite modülleri 5-29 GPa aralığında, aynı seviyedeki Poisson oranı ise 0.04-0.16 aralığında elde edilmiştir (Çizelge 5).

İncelenen yan kayaçlar genelde benzer birim hacim ağırlıklar sunmaktadırlar. Bunun yanında ÖY 2 ve 6'daki kumtaşları diğer yan kayaçlara göre daha yüksek dayanım değerleri göstermektedir (Çizelge 5).

\section{DAYKLARIN DAYANIM VE DEFORMASYON ÖZELLIKLERİ}

Dayklar ortalama olarak $170 \mathrm{MPa}$ gibi yüksek tek eksenli sıkışma dayanımı sunmaktadır. Farklı bölgelerden alınan dayk örneklerine ait UCS değerleri arasında farklılıklar görülse de aynı lokasyondan alınan dayk örnekleri genelde birbirleriyle uyumlu dayanım değerleri vermektedir. Dikkat çekici derecede düşük dayanım değerleri genelde önceden var olan ve karot alma işlemi sırasında görülmeyen kırıklar boyunca yenilen örneklerden elde edilmiştir (Şekil 3 ve Çizelge 4). Bununla beraber, Tapponier ve Brace (1976), Eberhardt vd. (1999), Ündül vd. (2015) ve Ündül (2016)'nın belirttikleri gibi, içyapıdaki çok küçük değişimler kayaç davranışında önemli değişimlere yol açabilmektedir. Çalışılan kayaçlarda hamur malzemesi ile fenokristal oranları sayısal olarak ifade edilmese de gözlemsel olarak farklılıklarının olduğu belirgindir. Bu farklılıklar iç yapıdaki değişimleri oluşturmaktadır (Şekil 3 ve Çizelge 4).

Çizelge 5. Yan kayaçlara ait fiziksel ve mekanik özellikler.

Table 5. Physical and mechanical properties of the host-rocks.

\begin{tabular}{|c|c|c|c|c|c|c|c|c|c|c|c|}
\hline $\begin{array}{c}\text { Örnek } \\
\text { Yeri }\end{array}$ & Kaya türü & $\begin{array}{l}\text { Örnek } \\
\text { say1s1 }\end{array}$ & $\begin{array}{c}\gamma \\
\left(\mathrm{kN} / \mathrm{m}^{3}\right)\end{array}$ & $\mathrm{n}_{\text {etkin }}$ & $\begin{array}{c}\mathrm{E} \\
(\mathrm{GPa})\end{array}$ & $v(-)$ & $\sigma(\mathrm{MPa})$ & $\begin{array}{l}\sigma_{C I, \text { cap }} \\
(\mathrm{MPa})\end{array}$ & $\begin{array}{c}\text { BTS } \\
(\mathrm{MPa})\end{array}$ & $\begin{array}{c}\mathrm{Vp} \\
(\mathrm{km} / \mathrm{s})\end{array}$ & Kaynak \\
\hline $1 \mathrm{~A}-1 \mathrm{~B}$ & İri taneli arkoz & 5 & $24.7-25.8$ & $2.3-6.8$ & 12.1 & 0.04 & $28-69$ & 27 & 5.2 & $2.5-3.8$ & $*$ \\
\hline $1 \mathrm{~A}-1 \mathrm{~B}$ & İnce taneli arkoz & - & 26.8 & & $5-8$ & & $33-44$ & & $\begin{array}{c}3.4- \\
5.0\end{array}$ & & $* *$ \\
\hline 2 & Kumtaş1 & 7 & $26.3-27.1$ & $1.5-2.1$ & & & $104-158$ & & $5.7-14$ & $4.5-4.8$ & $*$ \\
\hline 2 & Kireçtaş1 & 5 & $24.1-24.7$ & $1.5-2.9$ & $39-57$ & $0.08-0.16$ & $53-90$ & $17-42$ & - & $5.6-6.8$ & $* * *$ \\
\hline $3,4,5$ & Silttaş1-Çamurtaş1 & 3 & $26.6-26.7$ & & $10-11$ & & $38-84$ & $22-23$ & $10-14$ & $2.9-3.1$ & * \\
\hline 6 & Kumtaş1 & 5 & $27.3-27.4$ & $0.05-0.1$ & $24-29$ & $0.06-0.11$ & $89-158$ & $27-37$ & $8-14$ & $5.4-4.7$ & * \\
\hline $8 \mathrm{~A}-8 \mathrm{~B}$ & Kireçtaş1 & - & 26.2 & & 13 & & $59-72$ & & $\begin{array}{r}5.4- \\
9.4 \\
\end{array}$ & & $* *$ \\
\hline
\end{tabular}

* Bu çalışma kapsamında elde edilen veriler

** Bilgin vd. (2008)'den derlenen veriler

*** Ündül vd. (2016)'dan derlenen veriler 
Çalışılan kayaçların Young modülü (E) ve Poisson oranları (v) UCS değerlerine göre daha dar bir aralıkta değerler sunmaktadır. ÖY 7 örnekleri diğer örneklere göre önemli derecede yüksek UCS değerleri sunmaktadır. ÖY 1B ve ÖY 2 örnekleri ise diğer örneklere göre daha düşük E ve v değerleri vermiştir. Tüm örneklere bakıldığında, E ve $v$ değerlerinin de nispeten dar aralıkta değiştiği görülmektedir (Çizelge 4 ve Şekil 5). Bu durum kayanın iç yapısıyla ilişkilidir. Tek eksenli sıkışma deneyinde örnekler üzerinde deney boyunca gerilme etkili olduğundan içyap1 tüm gerilme değerlerinde etkin olmaktadır.
Böylece, örneğin yüksek gerilmelerdeki kararsız kırık gelişsimi kayaçların tek eksenli sıkışma dayanımını belirlemektedir. Ancak E ve v değerleri, örneğin gerilme şekil değiştirme diyagramında erken gerilme evresindeki elastik bölgeden hesaplanır. Bu nedenle, söz konusu gerilme seviyeleri, tüm gerilme seviyelerinin sadece bir kısmını kapsar. Bu seviyeler, tek eksenli sıkışma dayanımına göre oldukça düşüktür ve iç yapının etkisi de bu nedenle sınırlı kalmaktadır. Böylece, UCS değerleri saçılım gösterirken, E ve v değerleri göreceli daha dar bir aralıkta değerler sunmaktadır (Şekil 5).

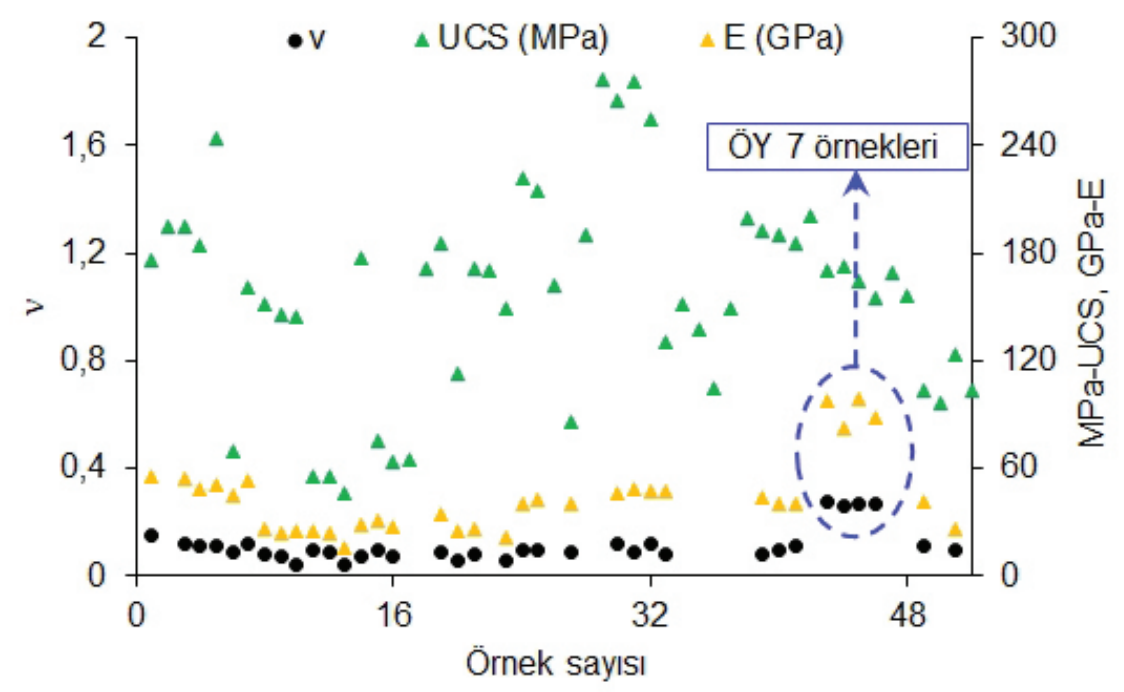

Şekil 5. Tek eksenli sıkışma dayanımı (UCS), elastisite modülü (E) ve poisson oranı (v) değerlerinin örneklere göre dağılımı (Ündül ve Çobanoğlu, 2017'den değiştirilerek).

Şekilde sağ düşey eksende, tek eksenli sıkışma dayanımı (UCS) için birim MPa, Elastisite modülü (E) için birim GPa olarak verilmiştir. E ve $v$ değerleri eksen etkisi göz ardı edildiğinde dahi UCS'e göre daha dar bir aralıkta dağılım göstermektedir.

Figure 5. Distribution of uniaxial compressive strength (UCS), modulus of elasticity (E) and poisson's ratio (v) with respect to the sample numbers (modified from Ündül and Çobanoğlu, 2017).

The unit for uniaxial compressive strength (UCS) is MPa and for the Elastic modulus (E) is GPa, respectively on the vertical axis on right. The values for $E$ and $v$ stand in a narrow range when the scale effect is ignored. 
Gevrek kayaçlar akma sınırında veya hemen sonrasında çok az boyuna deformasyon göstererek yenilmektedir. Dayklarda artan elastisite modülü ile yanal deformasyon düşey deformasyona göre önemli derecede artış göstermektedir (Şekil 6a). Bu bulguya göre; çalışılan kayaçlar için gevrekliğin elastisite modülü ile arttığı ifade edilebilir. Benzer bulgular Aydan vd. (2001) tarafından da elde edilmiştir. Şekil 6a'da ÖY 7 örneklerinin $\mathrm{E}$ ve $v$ değerlerinin diğer örneklere göre oldukça yüksek olduğu görülmektedir. Diyabaz örneklerinin diğer örneklerden faklı içyap1 özellikleri sunması, bu durumun nedeni olduğu düşünülmektedir ve bu veriler çıkartıldığında dahi grafik belirgin bir yönelim göstermeye devam etmektedir. Bu yeni durum için korelasyon katsayısı $\mathrm{r}=0.74$ olmaktadır. 6b'de de diyabazlara ait veri noktaları genel yönelimden farklilıklar göstermektedir. Çatlak oluşumunun başlangıcına ait gerilme seviyeleri $\left(\sigma_{\mathrm{cl}}\right)$ ve en yüksek dayanım $(\sigma)$ arasındaki ilişki bu veri noktaları olmadığında yine aynı oranı vermektedir.

Mekanik özelliklerin birbirleriyle olan ilişkilerinin anlaşılması için çoklu regresyon analizleri yapılmıştır. Bu kapsamda elde edilen çoklu lineer ilişkiler Çizelge 6'da verilmiştir. Çoklu regresyon analizleri elastisite modülü ve UCS değerlerinin Poisson oranı üzerindeki görünür etkisini ifade etmektedir. Benzer şekilde Poisson oranı ve BTS'in de Young modülüne etkisi belirgindir.
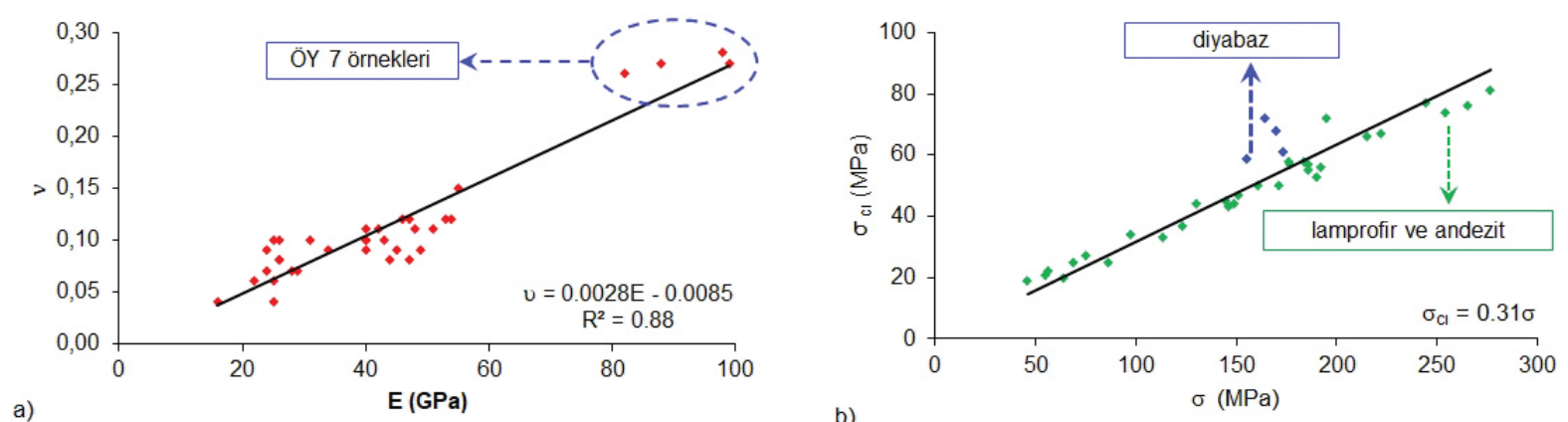

Şekil 6. Dayanım ve deformasyon parametreleri arasındaki ilişkiler a) Poisson oranının Young modülüne göre değişimi (Ündül ve Çobanoğlu, 2017'den değiştirilerek), b) Çatlaklanma başlangıcı gerilme seviyesinin tek eksenli sıkışma dayanımına göre değişimi.

Figure 6. The relationships between strength and deformation parameters a) the variation of Poisson's ratio with respect to Young's modulus (modified from Ündül and Çobanoğlu, 2017), b) the variation of crack initiation stress level with respect to uniaxial compressive strength.

İncelenen dayklarda çatlak oluşumunun başlangıcı, tek eksenli sıkışma dayanımının yaklaşık 0.31 'i seviyelerine eriştiğinde başlamaktadır. Şekil 6a'da verilen E ve v arasındaki ilişkilere benzer şekilde, Şekil

\section{Gevrekliğin Değerlendirilmesi}

Basit regresyon analizlerine göre, fiziksel ve mekanik özellikler ile $\mathrm{B}_{1}$ gevreklik değerleri arasında herhangi bir ilişki saptanamamıştır. Ancak çoklu regresyon analizleri dayanım, 
çekme gerilmesi, elastisite modülü ve Poisson oranlarının $\mathrm{B}_{1}$ değerlerini etkilediğini ortaya koymaktadır (Çizelge 6). Diğer yandan, Altındağ (2000) artan B değerleriyle kayaçların gevreklik özelliklerinin arttığını ifade etmiştir. Çalışılan kayaçların $\mathrm{B}_{2}$ değerleri tek eksenli sıkışma dayanımı ve Brazilian dolaylı çekme dayanımları ile ayrı ayrı görünür ilişkiler sunduğu basit regresyon analizleriyle belirlenmiştir (Şekil 7). Ayrıca çoklu regresyon analizlerine göre dayanım, çekme dayanımı, elastisite modülü ve Poisson oranının $\mathrm{B}_{2}$ üzerindeki etkileri Çizelge 6'da sunulmuştur. Çoklu regresyon analizleri dayanım ve deformasyon özelliklerinin, çalışılan kayaçların gevreklik özeliklerine önemli oranda etki ettiğini göstermektedir.

Çizelge 6. Çoklu regresyon analiz sonuçları.

Table 6. Results of the multiple regression analyses.

\begin{tabular}{lc}
\hline \multicolumn{1}{c}{ İlişkiler } & $\mathrm{r}$ \\
$v=-0.019+(0.002 E)-(0.00103 B T S)$ & 0.96 \\
$v=0.0069+(0.002 E)-(0.00013 \sigma)$ & 0.95 \\
$v=0.01+(0.00286 E)-(0.00018 \sigma)+$ & 0.96 \\
$(0.00097 B T S)$ & 0.95 \\
$\mathrm{E}=7.89+(323.36 v)+(0.072 \mathrm{BTS})$ & 0.99 \\
$\mathrm{~B}_{1}=16.07+(0.11 \sigma)-(1.79 B T S)+(0.02 E)$ & 0.99 \\
$\mathrm{~B}_{1}=16.00+(6.4 v)+(0.11 U C S)-(1.80 B T S)$ & 0.90 \\
$\mathrm{~B}_{1}=20.55+(0.09 \sigma)-(1.84 B T S)$ & 0.81 \\
$\mathrm{~B}_{1}=0.120+(0.18 \sigma)-\left(0.27 \sigma_{C I}\right)$ & 0.99 \\
$\mathrm{~B}_{2}=-1068+(5.06 \sigma)+(107.49 B T S)-(0.69 E)$ & 0.77 \\
$\mathrm{~B}_{2}=-92+(0.85 \sigma)+\left(16.21 \sigma_{C I}\right)$ & 0.74 \\
$\mathrm{~B}_{2}=-309+(5.60 \sigma)-\left(57.39 V_{p}\right)$ & \\
\hline
\end{tabular}

\section{Dayk ve Yan Kayaçların Birlikte Bulunması ve Bulguların Uygulamada Kullanılması}

İncelenen magmatik kayaçların farklı tortul kayaçlarla ayrımlı kayaç uyumsuzlukları vardır. $\mathrm{Bu}$ durum farklı dayanım ve farklı deformasyon özellikleri sunan ortamları oluşturmaktadır. Şekil 8 çekme dayanımı, Young modülü ve UCS değerlerinin dayklar ve sokulum yaptıkları yan kayaçlarla aralarındaki dayanım ve deformasyon farklılıklarını göstermektedir. Ayrıca Şekil 9'da daykların ve yan kayaçların gerilme şekil değiştirme grafikleri sunulmuştur. Her grafik aynı örnek noktasından alınan dayk ve yan kayaç örneğine ait verileri göstermektedir (Şekil 2).

Çizelge 4 ve Çizelge 5'te verilen ve Şekil 8 ve Şekil 9'da sunulduğu üzere dayklar eksenel yükler altında yan kayaçlara göre daha yüksek dayanım özelliği sunmaktadır. Daykların UCS değerleri farkl1lık gösterse de yük altındaki davranışları benzer olup yenilme anında gevrek davranırlar. Bununla birlikte, ÖY 2 noktasındaki kireçtaşı örnekleri dışında tüm sedimenter kayaçlar dayklara göre daha düşük elastisite modülü değerleri vermektedir (Şekil 9).

Şekil 10 ve Şekil 9'da gerilme şekil değiştirme grafikleri verilen örneklere ait enine ve boyuna şekil değiştirme değerlerinin uygulanan tüm yük kademelerindeki değişimini göstermektedir. Dayklar genel olarak boyuna şekil değiştirmenin \%0.6's1 mertebelerine kadar dereceli bir şekilde yanal şekil değiştirme göstermektedir. $\mathrm{Bu}$ seviyeden sonra yanal şekil değiştirmedeki artış belirgindir. Sedimenter kayaçlar için enine ve boyuna şekil değiştirmeleri daha değişkendir. Bu durum sedimenter kayaçları oluşturan tanelerin farklı boylarda olmasından bu durum kaynaklanmaktadır. Diğer taraftan, yumrulu kireçtaşı ve iri taneli kumtaşlarına ait grafiklerde enine şekil değiştirmelerin yaklaşı $\% 0.02$ seviyelerinden sonra enine şekil değiştirmelerde ani yükselişler gelişmiştir (Şekil $10)$. 


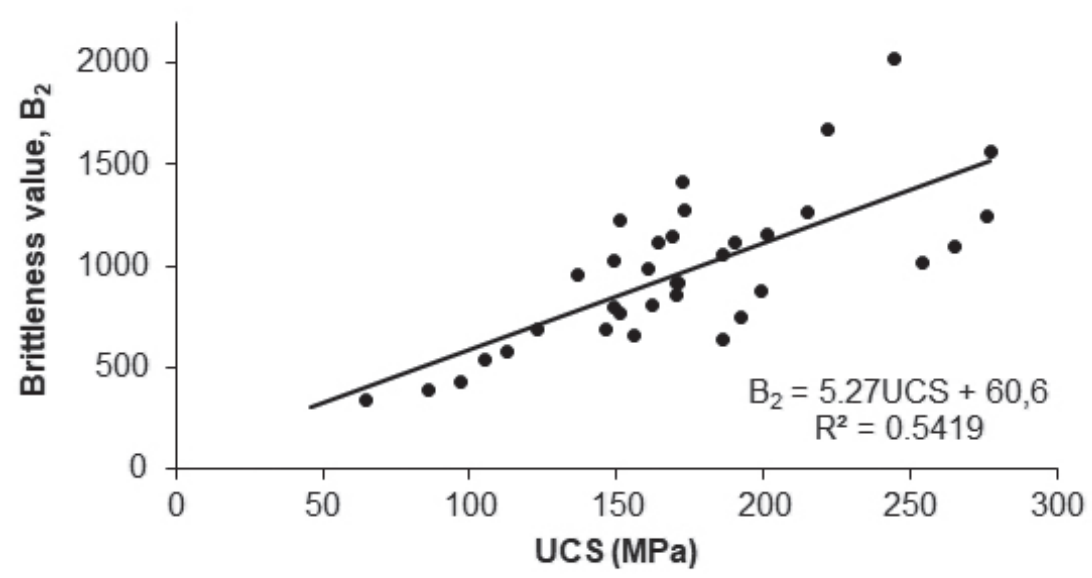

Şekil 7. Kayaçların gevreklik değeri $\left(\mathrm{B}_{2}\right)$ ile tek eksenli sıkışma dayanımı arasındaki ilişki. Çizgisel olmayan ilişki kullanıldığında korelasyon katsayısı $\left(\mathrm{R}^{2}\right) 0.68$ olmaktadır.

Figure 7. The relationship between brittleness $\left(B_{2}\right)$ and the coefficient of correlation $\left(R^{2}\right)$ is 0.68 in case non-linear trend of the uniaxial compressive strength of the rocks is utilized.

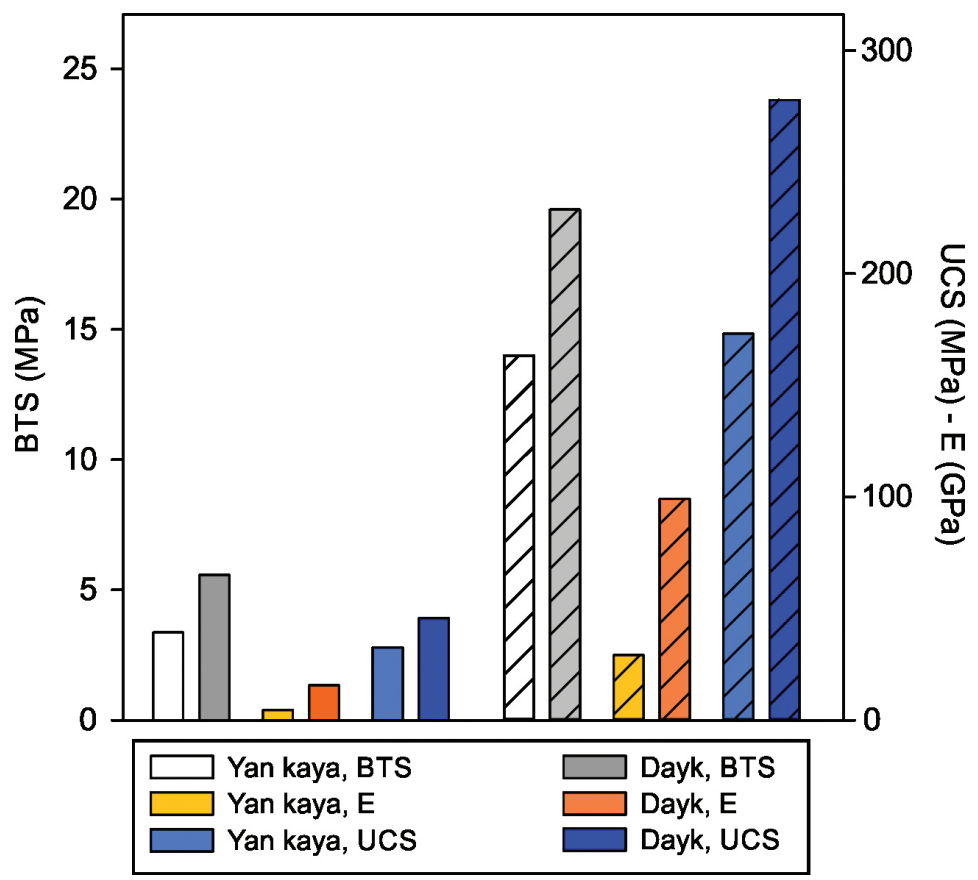

Şekil 8. Daykların ve yan kayaçların, Brazilyan dolaylı çekme dayanımı (BTS), Young modülü (E) ve tek eksenli sıkışma dayanımı (UCS) değerlerinin en düşük ve en yüksek değerlerinin görünümüi. Taralı kutular en yüksek, tarama yapılmayan kutular en düşük değerleri göstermektedir.

Figure 8. Maximum and minimum values for the Brazilian tensile strength (BTS), the Young's modulus (E) and the uniaxial compressive strength (UCS) of dikes and host rocks. Dashed boxes show the maximum, empty boxes show the minimum values. 

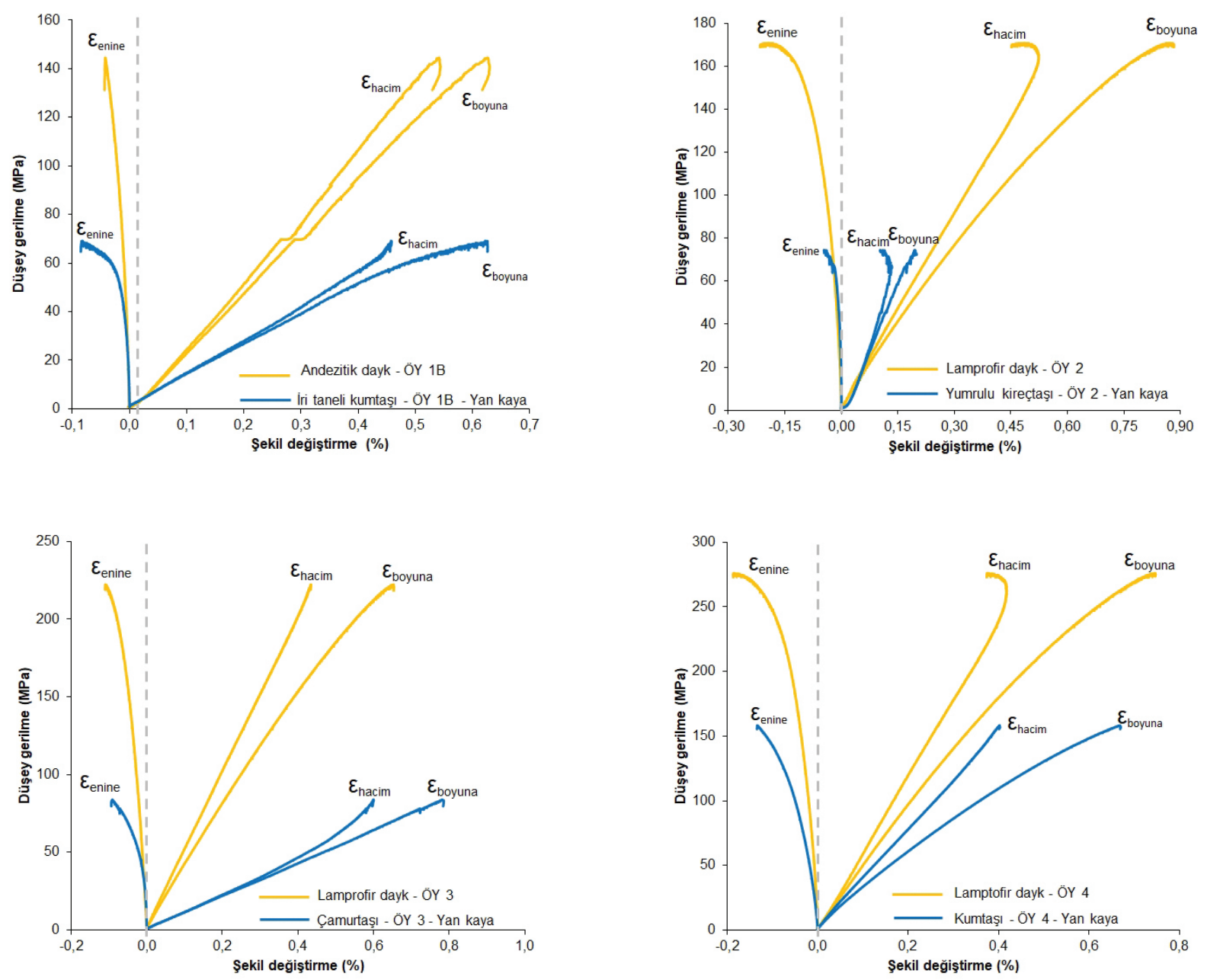

Şekil 9. Daykların ve yan kayaçların gerilme-şekil diyagramları a) andezitik dayk ile iri taneli kumtaşı - ÖY1, b) lamprofir dayk ile yumrulu kireçtaş1 - ÖY2, c) lamprofir dayk ile çamurtaş1 - ÖY3, d) lamprofir dayk ile kumtaş1 ÖY4 (Şekil 9c ve d (Ündül ve Çobanoğlu, 2017'den değiştirilerek kullanılmışır)).

Figure 9. The stress - strain diagrams of dikes and host rocks a) andesitic dike and coarse-grained sandstone -ÖY1, b) lamprophyre dike and nodular limestone - ÖY2, c) lamprophyere dike and mudstone - ÖY3, d) lamprophyere dike and sandstone - ÖY4 (Figure $9 c$ and d modified from Ündül and Çobanoğlu (2017)). 


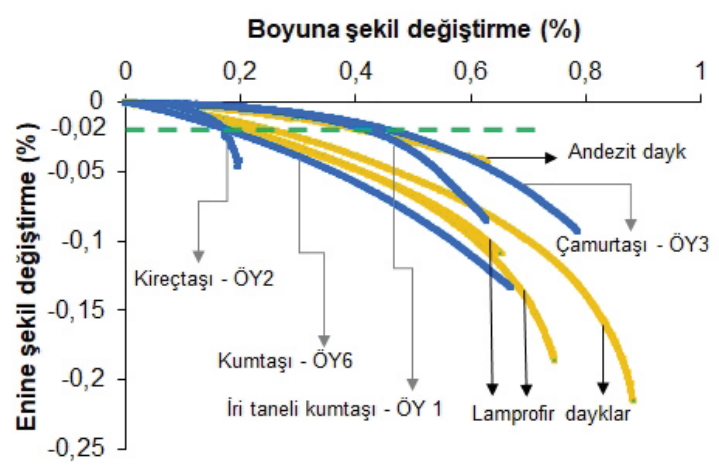

Şekil 10. Dayklar ve yan kayaçlarda Poisson etkisi.

Figure 10. Poisson effect on the dikes and host rocks.

Araştırmacılar masiften orta derecede çatlaklı kayaç kütlelerine kadar olan farklı ortamlarda yeraltı kaya yapılarının uzun dönem duraylılıklarının çatlaklanma başlangıcı gerilme seviyeleriyle yakından ilişkili olduğunu ifade etmişlerdir (Martin, 1997; Hajiabdolmajid vd., 2002; Martin ve Christiansson, 2009; Amann vd., 2011; Nicksiar ve Martin, 2013). Ayrica, Lee vd. (2004) ve Diederichs (2007) aynı kayaç ortamlarında $s_{c} / \sigma_{t}$ oranının kavlaklanma analizlerinde kullanılabileceğini belirtmişlerdir. $\mathrm{Bu}$ çalışmada $\sigma_{c} / \sigma_{t}$ oranı gevreklik değeri ( $\mathrm{B}_{1}$, Eşitlik 2) olarak ele alınmıştır. Bunun yanında, Lee vd. (2004) ve Diederichs (2007) kavlaklanmanın artışının daha az kırıklı ve daha yüksek $s_{c} / \sigma_{t}$ oranı ile arttı̆ğnı belirtmişlerdir. Diederichs (2007) masif - orta çatlaklı kaya kütleleri için $s_{c} / \sigma_{t}$ oranının 15'in üzerinde olduğu durumlarda kavlaklanma analizlerinin yapılması gerektiğini ve çatlaklanma başlangıcı gerilme seviyelerinin süreksizlik analizlerinden daha önemli olduğunu ifade etmiştir. Bu çalışmada incelenen dayklar yan kayalarını kestikleri için göreceli olarak daha gençtirler ve tektonik etkilerden daha az etkilenmişlerdir. Bu nedenle, daha az sayıda süreksizlik içermektedirler ve süreksizlik sı1klıkları oldukça düşüktür (Şekil 2). Dayklara ait $s_{c} / \sigma_{t}$ oran 19.26 ve 35.62 arasinda değişmektedir (Çizelge 4). Pekçok örneğin $s_{c} /$ $\sigma_{t}$ oranı 15 'ten fazladır (Şekil 11). Daykların daha az süreksizlik içermeleri ve yüksek $\sigma_{c} / \sigma_{t}$ oranına sahip olmaları nedeniyle yer aldıkları bölgelerde kavlaklanma analizlerinin yapılması karşılaşılacak sorunların azaltılması yönünden önemlidir.

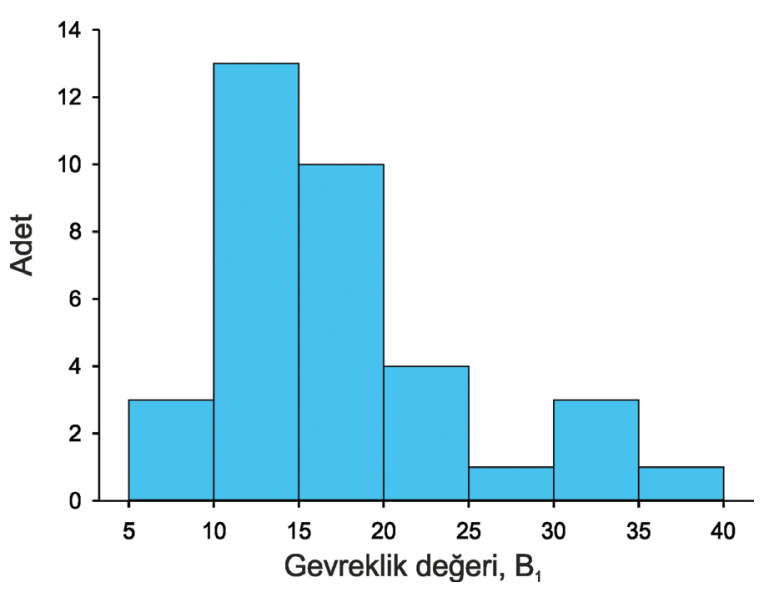

Şekil 11. Daykların gevreklik değerlerine $\left(B_{1}\right)$ ait histogram.

Figure 11. Histogram of brittleness values for the dikes $\left(B_{p}\right)$.

Daykların çatlaklanma başlangıcı gerilme seviyeleri $\quad 0.28-0.44$ UCS seviyelerindedir. Daykların yan kayalarında da benzer değerler elde edilmiştir (0.23-0.39, Çizelge 5). Ancak yan kayaların UCS değerlerinin dayklara oranla daha düşük seviyelerde olduğu unutulmamalıdır.

Çizelge 4 ve Çizelge 5'te belirtildiği gibi, çatlaklanma UCS'in yaklaşık üçte biri seviyelerinde başlamaktadır. Göreceli düşük gerilme seviyelerinde başlayan çatlaklanma süreçleri tünel açımı sırasında çeşitli sorunlar yaratmaktadır. $\mathrm{Bu}$ sorunların başında tünel 
aynası ve desteksiz kısımlarda meydana gelen duraysızlıklar, TBM sıkışmaları ve tünelcilik faaliyetlerinde aksamalara dayk - yan kaya sınırlarında ve dayk kütlelerinin yer aldığ 1 bölgelerde sıklıkla bildirilmektedir (Bilgin, 2016). Bu olgular daykların çatlaklanma başlangıcı gerilme seviyeleri ile yenilme sırasında gösterdikleri gevrek davranışlara bağlıdır. Bunlara ek olarak, dayklar ile sedimenter yan kayaçların süreksizlik sıklıkları arasında önemli farklar vardır. Daykların dayanım ve deformasyon özellikleri, nispeten daha az süreksizlik içermeleri ve yenilme anında gevrek davranış göstermeleri nedeniyle sorunlar yarattığ 1 belirlenmiştir. $\mathrm{Bu}$ sorunlar mühendislik girişimlerinin planlama ve projelendirme aşamalarında daykların jeomühendislik özelliklerinin ayrıntılı olarak incelenmesini gerektirmektedir.

\section{SONUÇLAR}

Bu çalışmada İstanbul'da yer alan daykların fiziksel ve mekanik özellikleri ayrıntılı olarak incelenmiştir. Daykların gevreklik özellikleriyle birlikte tek eksenli yükler altındaki dayanım ve deformasyon özellikleri belirlenmiştir. Bunlara ek olarak, daykların ve yan kayaların dayanım ve deformasyon özellikleri birbirleriyle karşılaştırılmıştır. Çalışma kapsamında elde edilen sonuçlar aşağıda özetlenmiştir.

- Daykların tek eksenli sıkışma dayanımları 46-277 MPa arasında değişmektedir. Young modülleri ise 16-99 $\mathrm{GPa}$ arasında yer alır, Poisson oranları ise oldukça düşüktür ve 0.04-0.28 mertebelerindedir. Diyabaz örnekleri hariç daykların elastisite modülleri (16-55 GPa) ve Poisson oranlar1 (0.04$0.15)$ nispeten dar bir aralıktadır. Gevreklik değerleri ise $B_{1}$ eşitliğine göre 9.3-35.6, $\mathrm{B}_{2}$ eşitliğine göre ise 338-2025 değerleri arasında değişmektedir.
- Yan kayaçların tek eksenli sıkışma dayanımları 33-158 MPa, elastisite modülleri ise 5-29 GPa arasındadır.

- Daykların çatlaklanma başlangıcı gerilme seviyeleri tek eksenli sıkışma dayanımının 0.22-0.44'ü seviyelerinde olup belirlenen en uygun doğruya göre $\sigma_{\mathrm{c}} / \sigma$ oran1 0.31 'dir.

- Çoklu regresyon analizlerine göre, elastisite modülü (E) ve en yüksek dayanımın (UCS) birlikte etkisi ile Poisson oranı arasında kuvvetli bir ilişki gözlenmiştir $(\mathrm{r}=0.95)$. Benzer şekilde, Posisson oranı ve dolaylı çekme dayanımının elastisite modülü üzerindeki etkisi oldukça yüksektir ( $(\mathrm{r}=0.95)$.

- İncelenen dayklar yan kayaçları kestikleri için göreceli daha gençtir $\mathrm{Bu}$ nedenle daha az sayıda tektonik kökenli süreksizlikler içerirler. Daykların yer aldığı bölgede inşa edilecek yer altı kaya yapılarında $s_{c} /$ BTS oranı ve çatlaklanma başlangıcı gerilme seviyelerinin göz önünde bulundurulduğu kavlaklanma analizlerinin yapılması uygun olacaktır. Daykların tek eksenli sıkışma dayanımları değişkenlik gösterse de yenilme sırasında gevrek kırıldığı göz ardı edilmemelidir.

- Çoklu regresyon analizlerine göre, dayanım ve deformasyon özelliklerinin çalışılan kayaçların gevreklikleri üzerinde önemli bir etki yaptığ 1 belirlenmiştir.

- Yan kayaçlar dayklara göre daha düşük dayanım ve elastisite modülü değerleri sunmaktadır. Ayrıca eksenel yükler altındaki davranışları dayklardan farklıdır. Daykların ve yan kayaçların dayanım ve deformasyon özelliklerindeki bu farklar nedeniyle yeraltı kayaç yapılarının inşalarından önce bu kayaçların birlikteliklerinden doğabilecek sorunlara yönelik ayrıntılı jeomekanik ve jeo-mühendislik çalışmaları yapılmalıdır. 
- $\mathrm{Bu}$ çalışmada elde edilen sonuçlar İstanbul bölgesindeki kayaçlar üzerinde yapılmış olup farklı litolojik özelliklere sahip kayaçlarda yapılacak çalışmalarda ilgili litoloijlere ait örnekler üzerinde benzer deneyler yapılarak sonuçlar değerlendirilmelidir. Ayrıca bu çalışmadaki örnek yerlerinden farklı olarak değişik yerlerden de örnekler alınarak çalışmanın genişletilmesi özellikle İstanbul'daki yeraltı yapılarında daha güvenilir verilerin elde edilmesini sağlayacağı unutulmamalıdır.

\section{Katkı Belirtme}

Yazarlar, İsviçre ETH Mühendislik Jeolojisi Kürsüsünden Prof. Dr. Simon Löw ve Dr. Florian Amann'a tek eksenli sıkışma deneylerinin gerçekleştirilmesi sırasında sağladıkları imkanlar için ve İstanbul Üniversitesi Jeoloji Mühendisliği Bölümünden Doç. Dr. Namık Aysal'a XRD çalışmaları sırasında yaptığı katkılardan dolayı teşekkür ederler. Bu çalışma, TÜBITTAK tarafindan 116Y349 numaralı proje ile desteklenmektedir.

\section{KAYNAKLAR}

Altındağ, R. 2000. The role of rock brittleness on analysis of percussive drilling performance, (in Turkish), Proceedings of 5th National Rock Mechanics 2000, 105-112.

Amann, F., Button, E.A., Evans, K.F., Gischig, V.S., Blümel, M., 2011. Experimental study of the brittle behavior of clay shale in short-term unconfined compression. Rock Mechanics Rock Engineering, 44 (4), 415-430.

Andreev, G. E., 1995. Brittle failure of rock materials: test results and constitutive models. A. A. Balkema, Rotterdam, p. 446.
Arıkan, F., Ulusay R., Aydın N., 2007. Characterization of weathered acidic volcanic rocks and a weathering classification based on a rating system. Bulletin of Engineering Geology and the Environment, 66, 415-430.

Aydan, Ö., Geniş, M., Akagi, T., Kawamoto, T., 2001. Assessment of susceptibility of rock bursting in tunnelling in hard rocks. Proc. of the International Symposium on Modern Tunneling Science and Technology (eds. Adachi), Swets\&Zeitlinger, Vol. 1, 391-396.

Aysal, N., Keskin M., Peytcheva I., Duru O., Akgündüz S., 2015. Geochronology, geochemistry and isotope systematics of a mafic-intermediate dyke complex in the İstanbul zone, Northern Turkey. Goldschmidt 2015, Prag, CEK CUM., 16-21, 155-155.

Biberoğlu, S., 2006. Engineering geological and geotechnical properties of volcanic dikes along the Marmaray Project Route, İstanbul. 5s. (in Turkish, unpublished)

Bieniawski, Z.T., 1967. Mechanism of brittle failure of rock part I-theory of fracture process. International Journal of Rock Mechanics Mining Science Geomechanics Abstracts, 4 (4), 395406.

Bilgin, N., Çopur, H., Balci, C., Tumac, D. 2008. The selection of a TBM using full scale laboratory tests and comparison of measured and predicted performance values in Istanbul KozyatagiKadikoy metro tunnels. World Tunnel Congress 2008 Proceedings Book, 1509-1516.

Bilgin, N., 2016. An appraisal of TBM performances in Turkey in difficult ground conditions and some recommendations. Tunnelling and Underground Space Technology, 57, 265-276.

Bilgin, N., Çopur, H., Balci, C. 2016. TBM excavation in difficult ground conditions: case studies from Turkey. Wiley, $354 \mathrm{p}$.

Blindheim, O.T., Bruland, A., 1998. Boreability testing. Norwegian TBM tunnelling 30 years of Experience with TBMs in Norwegian Tunnelling. Norwegian Soil and Rock Engineering Association, Publication no 11, 29-34. 
Dalgıç, S., 2000. The influence of weak rocks on excavation and support of the Beykoz Tunnel, Turkey. Engineering Geology, 58, 137-148.

Dalgıç, S., 2002. A comparison of predicted and actual tunnel behavior in the Istanbul Metro, Turkey. Engineering Geology, 63, 69-82.

Damjanac, B., Fairhurst, C., 2010. Evidence for a long-term strength threshold in crystalline rock. Rock Mechanics and Rock Engineering, 43 (5), 513-531.

Diederichs, M.S., 2007. The 2003 Canadian Geotechnical Colloquium: Mechanistic interpretation and practical application of damage and spalling prediction criteria for deep tunneling. Canadian Geotechnical Journal, 44, 1082-1116.

Diederichs, M.S., Kaiser, P.K., Eberhardt, E., 2004. Damage initiation and propagation in hard rock during tunnelling and the influence of near-face stress rotation. International Journal of Rock Mechanics Mining Science Geomechanics Abstracts, 41 (5), 785-812.

Eberhardt, E., Stimpson, B., Stead, D., 1999. Effect of grain size on the initiation and propagation threshold of stress-induced brittle fracture. Rock Mechanics and Rock Engineering, 32 (2), 81-99.

Eroskay, S.O., 1985. Graywackes of İstanbul region. Derin Kazılar ve İksa Metodları Sempozyumu, Boğaziçi Üniversitesi, 141-144.

Eyigün, Y., 2014. The bearing capacities of piles in İstanbul greywackes. PhD. Thesis, İstanbul Teknik Üniversitesi, 219 s (in Turkish).

Fugro, 2010. Geotechnical report Eurasia tunnel project investigation data. Geotechnical Data Bosphorus Railway Crossing, Vol 1-2, İstanbul Turkey.

Gong, Q. M., Zhao, J., 2007. Influence of rock brittleness on TBM penetration rate in Singapore granite. Tunnelling and Underground Space Technology, 22, 317-324.

Hajiabdolmajid, V., Kaiser, P.K., Martin, C.D., 2002. Modelling brittle failure of rock. International Journal of Rock Mechanics Mining Science Geomechanics Abstracts, 39, 731-741.
Hajiabdolmajid, Y., Kaiser, P., 2003. Brittleness of rock and stahility assessment in hard rock tunnelling. Tunnelling and Underground Space Technology, 18, 35-48.

Heidari, M., Khanlari G.R., Torabi-Kaveh M., Kargarian, S., Saneie, S., 2014. Effect of porosity on rock brittleness. Rock Mechanics Rock Engineering, 47, 785-790.

Hetenyi, M., 1966. Handbook of experimental stress analysis. Wiley, New York, p 15.

Holt, R. M., Fjær, E., Stenebråten, J.F., Nes, O. M., 2015. Brittleness of shales: Relevance to borehole collapse and hydraulic fracturing. Journal of Petroleum Science and Engineering, 131, 200-209.

Hucka, Y., Das B., 1974. Brittleness determination of rocks by different methods. International Journal of Rock Mechanics Mining Science Geomechanics Abstract, 11, 389-392.

International Society for Rock Mechanics (ISRM), 1981. Rock characterization testing and monitoring - ISRM Suggested Methods. In: Brown, E.T. (Ed.), Pergamon, New York.

International Society for Rock Mechanics (ISRM), 2007. The complete ISRM suggested methods for rock characterization, testing and monitoring. Kozan, Ankara, pp 1974-2006.

İstanbul Büyükşehir Belediyesi (IBBB), 2011. İstanbul İl Alanının Jeolojisi. İstanbul Büyükşehir Belediyesi Planlama ve İmar Daire Başkanlığı, Editör Necdet Özgül, $333 \mathrm{~s}$.

Kahraman, S., 2002. Correlation of TBM and drilling machine performances with rock brittleness. Engineering Geology, 65 (4), 269-283.

Kaiser, P.K., Cai, M., 2012. Design of rock support system under rockburst condition. Journal of Rock Mechanics and Geotechnical Engineering, 4 (3): 215-227.

Kaya, O., 1973. The Devonian and lower Carboniferous stratigraphy of the İstinye, Bostancı and Büyükada subareas. Kaya O (ed.), Paleozoic of İstanbul, Ege Üniversitesi Fen Fakültesi Kitaplar Serisi, 40, 1-143. 
Ketin, İ., 1941. Das granitmassiv westlich von Alemdağ. İstanbul Üniversitesi Enstitüsü Neşriyatı, 7, 1-13.

Ko, T.Y., Kim, T.K., Son, Y., Jeon, S., 2016. Effect of geomechanical properties on Cerchar Abrasivity Index (CAI) and its application to TBM tunnelling. Tunnelling and Underground Space Technology, 57, 99-111.

Lajtai, E.Z., 1974. Brittle fracture in compression. International Journal of Fracture, 10 (4), 525536.

Lee, S.M., Park, B.S., Lee, S.W. 2004. Analysis of rockbursts that have occurred in a waterway tunnel in Korea. Proceedings of the ISRM SINOROCK 2004 Symposium, International Journal of Rock Mechanics and Mining Sciences, 41(1), 911-916.

Martin, C.D., 1997. Seventeenth Canadian Geotechnical Colloquium: the effect of cohesion loss and stress path on brittle rock strength. Canadian Geotechnical Journal, 34, 698-725.

Martin, C.D., Christiansson, R., 2009. Estimating the potential for spalling around a deep nuclear waste repository in crystalline rock. International Journal of Rock Mechanics and Mining Sciences, 46 (2), 219-228.

Meng, F., Zhou, H., Zhang, C., Xu, R., Lu, X., 2015. Evaluation methodology of brittleness of rock based on post-peak stress-strain curves. Rock Mechanics and Rock Engineering, 48, 17871805 .

Nicksiar, M., Martin, C.D., 2013. Crack initiation stress in low porosity crystalline and sedimentary rocks. Engineering Geology, 154, 64-76.

Okay, A.C., 1948. Şile Mudarlı, Kartal ve Riva arasındaki bölgenin jeolojik etüdü. İstanbul Üniversitesi Fen Fakültesi Mecmuas1, 8/4, 311335.

Önalan, M., 1981. İstanbul Ordovisiyen ve Silüriyen istifinin çökelme ortamları. İstanbul Yerbilimleri Dergisi., c. 2, 3-4, 161-177.

Önalan, M., 1982. Pendik bölgesi ile adaların jeolojisi ve sedimenter özellikleri. İstanbul Üniversitesi Yerbilimleri Fakültesi, Doçentlik Tezi, 156s.
Özgül, N., 2012. Stratigraphy and some structural features of the İstanbul Palaeozoic. Turkish Journal of Earth Sciences, 21, 817-866.

Penck, W., 1919. Grundzüge der Geologie des Bosporus, Veröffentlichungen Des Instituts Für Meereskunde, Geol.- Nalturw, Reihe, H. 4, Berlin.

Tapponnier, P., Brace,W.F., 1976. Development of stress-inducedmicrocracks in Westerly granite. International Journal of Rock Mechanics Mining Science Geomechanics Abstracts, 13, 103-112.

Tchihatcheff, P. de, 1864. Le Bosphore et Constantinople, avec carte geologique, Paris p.232.

Ündül, Ö., Amann F., Aysal, N., Plötze, M., 2015. Micro-textural effects on crack initiation and crack propagation of andesitic rocks. Engineering Geology, 193, 267-275.

Ündül, Ö., 2016. İstanbul Paleozoyik istifindeki dayklar ile bölgedeki diğer mağmatik kayaların gevreklik ve jeomekanik özelliklerinin araştırılması. TUBİTAK Projesi, 319316 (devam ediyor).

Ündül, Ö., Amann, F., Perras, M., Aysal, N., Çobanoğlu, B.C., 2016. Strength, deformation and cracking characteristics of limestones. Rock Mechanics and Rock Engineering: From the Past to the Future, Eurock 2016 Proceedings Book (Eds. Ulusay, R., Aydan, Ö., Gerçek, H., Hindistan, M.A., Tuncay, E.), p.181-185.

Ündül, Ö., Çobanoğlu, B., 2017. İstanbul'daki magmatik kayaların dayanım ve deformasyon özellikleri ile yan kayaçlar ile ilişkileri. Ulusal Mühendislik Jeolojisi ve Jeoteknik Sempozyumu, 12-14 Ekim, 245-252.

Varol, A., Dalgıç, S., 2006. Grouting applications in the İstanbul metro, Turkey. Tunnelling and Underground Space Technology, 21, 602-612.

Xia, Y. J., Li, L. C., Tang, C. A., Li, X. Y., Ma, S., Li, M., 2017. A new method to evaluate rock mass brittleness based on stress-strain curves of class I. Rock Mechanics and Rock Engineering, 50, 1123-1139. 
Yağız, S., 2009. Assessment of brittleness using rock strength and density with punch penetration test. Tunnelling and Underground Space Technology, 24 (1), 66-74.

Yıldırım, M., Tonaroğlu, M., Selçuk, M.E., Akgüner, C., 2013. Revised stratigraphy of the Tertiary deposits of İstanbul and their engineering properties. Bulletin of Engineering Geology and the Environment, 72, 431-420.
Zhishui, L.I.U., Zandong, S.U.N., 2015. New brittleness indexes and their application in shale/clay gas reservoir prediction. Petroleum. Exploration Development, 42(1), 129-137. 